\title{
Technical Competency Development Planning Model At The Regional Secretariat Of Purwakarta Regency
}

\author{
Wildan Sundari ${ }^{1}$, Edah Jubaedah ${ }^{2}$, Joni Dawud ${ }^{3}$ \\ Sekretariat Daerah Kabupaten Purwakarta ${ }^{1}$, Politeknik STIA LAN Bandung ${ }^{23}$
}

\{wildansundari@gmail.com $\left.{ }^{1}\right\}$

\begin{abstract}
This study aims to analyze and formulate an alternative model for planning the development of technical competence at the Regional Secretariat of Purwakarta Regency. The research method used is descriptive qualitative. Data collection techniques using interviews, document studies and supported by the distribution of questionnaires. The results showed that the planning for the development of technical competence of employees at the Regional Secretariat of Purwakarta Regency had not been implemented optimally. The determination of the policy for developing the technical competence of employees is still an annual program formality and has not been based on the results of a systematic analysis. Therefore, this study proposes a planning model for the development of technical competence of employees which is based on the profile of the organization and existing positions in the organization, the results of the identification of performance indicators and superior performance perspectives, and the results of comparisons between the competencies possessed by employees and those expected by the organization. These stages produce the competencies needed by employees in accordance with their job descriptions. The competency requirement plan is finalized and validated by the authorized official as an employee technical competency development plan for the following year's work program.
\end{abstract}

Keywords: technical competence, planning, development

\section{Introduction}

The main requirement for an organization to be able to survive, be independent, and competitive in the midst of such a rapid world development and technological advances towards an all-digital direction, namely the preparation of professional and competent personnel resources. The quality of human resources is determined by the extent to which the organization prepares or plans the competency development of its employees. Several organizations have carried out competency mapping with the help of external institutions, but there are still gaps in the alignment of individual behavior with the expected standards of behavior.

However, the facts on the ground show that the development of civil servant competencies is still a problem faced by the government. Empirical evidence from field studies shows a number of problems in developing the competence of civil servants. Sani, Rares, and Ogotan (2018) who reviewed the competency development of civil servants at the Education Office of 
Intan Jaya Regency, Papua Province, found that the implementation of the competency development program had not been able to reach all existing civil servants. Other problems are the lack of leadership support and commitment (Juhaeni, 2019), not using data from the competency assessment and performance of civil servants as a basis for determining competency development goals, and the lack of integration between the implementation of training and development with career management and talent segmentation (Pendit, 2012).

One of the many problems in developing civil servant competencies that are still less effective is related to the incompatibility of providing competency development with the needs of civil servants themselves. Saleh et.al (2013, in Ngindana \& Hermawan, 2019) stated that there is no relevance between education and training programs (training) followed by the fields of duty and work of civil servants themselves. This shows the dissonance between planning and the need for competency development. Whereas conceptually the effectiveness of the training competency development program is determined by one of them

This also happened at the Regional Secretariat of Purwakarta Regency, where there was a gap in the competence of the position expected by the organization with the requirements of the position held by the employee. Therefore, competency development planning is the answer to these problems. This position requirement applies to all positions, both structural, functional and implementing positions. The requirements for this position are the basis for the Regional Secretariat of Purwakarta Regency to conduct a job analysis, which is to compare information on positions held by employees with the job requirements set by the organization. The competency gaps found in the Regional Secretariat of Purwakarta Regency include the incompatibility of educational background required for a certain position with that of the employee. This means that the job requirements that have been prepared so far cannot be carried out absolutely or firmly, due to the limited number of employees.

The purpose and direction of developing employee competence in Purwakarta Regency, especially in the Purwakarta Regency Regional Secretariat is not yet clear. The apparatus capacity building program as one of the programs in the effort to develop employee competence that has been carried out so far is often not systematic, meaning that it does not go through the planning process.

Therefore, the output of participants after technical training is not in line with the organization's goal of intelligent and superior human resources. The process of preparing a competency development program plan at the Regional Secretariat of Purwakarta Regency is more of an empirical model, not based on objective analysis, tends to be direct instructions from the leadership, and the existing programs are only limited to carrying out annual routine activities.

The Regional Government of Purwakarta Regency does not yet have specific policies or regulations regarding planning for the development of technical competence for its employees. The priority of employee competency development planning policies is highly dependent on the direction and commitment of the leadership. The existing policies are more focused on the form of career development. The budget posture of the Purwakarta Regency Government in 2020 according to information obtained from the Head of the Purwakarta Regency Regional Finance and Assets Agency on February 5, 2020, which amounted to IDR 2,378 trillion and the Purwakarta Regency Government's concentration on employee competency development was approximately 2 billion or $0.084 \%$ of the total budget ceiling in a year.

The budget ceiling for competency development is spread across several regional apparatus organizations, and the allocation for the Regional Secretariat is Rp. 218,300,000, (two hundred and eighteen million three hundred thousand rupiah) - even though the number of employees in the Purwakarta Regency Regional Secretariat is 136 people. 
Based on the background and related problems, the researcher wants to analyze the planning for the development of technical competence of employees and formulate an alternative model of planning for the development of technical competence of employees at the Regional Secretariat of Purwakarta Regency.

\section{Literature Review}

Planning is the first function that has an important role that is quite fundamental because it will be the basis for the implementation of subsequent functions. The success or failure of the competency development process will depend on the extent to which the planning is carried out in a very thorough and focused manner. Terry (2005: 92) states: "Planning is the selecting and relating of the fact and the making and using of assumptions regarding the future in the visualization and formulation of proposed activations believed necessary to achieve desire result". Planning according to this opinion is the process of selecting and relating facts and making and using assumptions about the future by describing and formulating the activities needed to achieve the desired results.

Planning because it is a process, it relates to the steps of activities carried out by the organization to meet the needs and goals to be achieved in the field of HR. Shermon in Mukherjee (2011: 29) formulates a competency development planning model as can be seen in the following figure:

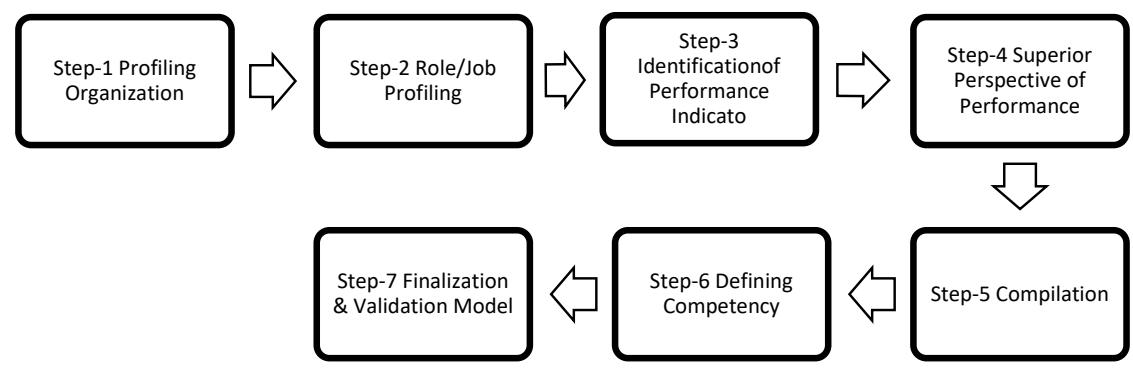

Fig 1. Steps of Competency Development Model (Mukherjee (2011: 29)

The first stage is organizational profiling, meaning that the technical competency development plan must be aligned with the organization's vision and mission as well as the organization's strategic plan. This relates to how to plan competency development in line with organizational goals. The second stage is role/job profiling, meaning that planning for technical competency development must also be able to demonstrate or describe the competencies expected by the organization as stated in the job specification and in accordance with the workload in the job description.

The third stage is the identification of performance indicators, which relates to the identification of performance indicators. The next stage is the superior perspective of performance, which is the assessment of superior performance. At this stage, an effective performance appraisal system is needed that is able to describe the real achievements and performance of employees in the field. 
The next stage is compilation, which means collecting the results of the comparison of the competency profile of civil servants with the competency standards of the position occupied and/or to be occupied. The results of this competency gap can be obtained through competency tests conducted by internal government assessors or in collaboration with independent assessors or can use the competency assessment method in the form of a superior-subordinate dialogue. The next stage is defining competency, which means determining technical competencies that are in accordance with organizational competency needs. In determining the development of technical competence will be more optimal if it is based on the interests of employees, so it is necessary to find the direction, interests, and talents of employees. The last stage is finalization and validation, which means that at this stage ratification of the needs and plans for developing technical competencies will be proposed to the staffing officers and authorized officials.

Spencer and Spencer (1993: 9) state that: "competency as an underlying characteristic of an individual that is causally related to criterion-referenced effective and/or superior performance in a job or situation". Based on this definition, it can be concluded that competence is an internal factor in the achievement of an employee's performance. Spencer \& Spencer (1993: 10) identified five characteristics of competence, namely: motives (motives), traits (traits), self-concept, knowledge (knowledge), skills (skills).

In principle, competence must be able to distinguish between superior work results (superior performance) and those that meet standards (effective performance). Superior performance is a form of implementation of competence that aims to achieve results above the set standards. While effective performance is the implementation of competencies that meet the desired minimum limit, so that it will be seen that there is a low performance (poor performance) which shows performance below the set standards. According to Causio and Award (in Soeprihanto, 2001: 9) superior work results (superior performance) have the following criteria: relevance, acceptability, reliability, sensitivity, practicality.

According to Law no. 5 of 2014 that technical competence is the ability of civil servants in certain technical fields to carry out their respective duties. For civil servants who have not met the competency requirements of the position, they need to follow technical training related to the competency requirements of their respective positions. Technical training is carried out to provide knowledge and/or mastery of skills in the field of tasks related to the work of Civil Servants (PNS) so that they are able to carry out their duties and responsibilities professionally.

\section{Research Method}

Based on the problems and objectives, this research uses a descriptive qualitative approach. The qualitative approach was chosen by the researcher because it was in accordance with the needs of this study to describe and examine in depth the planning model of technical competency development that was considered suitable at the Regional Secretariat of Purwakarta Regency. In this study, researchers obtained data on the comparison of the number of employees who are competent and in accordance with the qualifications of the position, with the number of employees who are incompetent and not in accordance with the qualifications of the position.

Researchers used primary data through interviews and questionnaire results which were processed as supporting or supporting data. Secondary data used include strategic plan documents, annual work plans, personnel data, job information, job analysis, or job evaluations.Data and information were collected from informants who are structural officials in echelon II, III, and IV as well as employees from the Planning, Development, Regional 
Development Research, Development Section, Organization and Administration Section, Personnel Subdivision, Personnel Agency and Human Resources Development. , Education and Training, Personnel Analyst, Personnel Manager.

Processing and analyzing data using qualitative procedures from Miles \& Huberman, starting from the stages of collecting, reducing, presenting, to verification and drawing conclusions. Data analysis was carried out by examining the contents of interview transcripts and documents that had been collected related to planning for employee competency development. Verification of data and information is carried out to build data credibility through source triangulation and technical triangulation.

Data from interviews are grouped according to aspects in the planning stages of employee competency development, which include organizational profiling, job profiling, identification of performance indicators, superior perspectives of performance, compilation, defining competency, to finalization and validation.

\section{Results And Discussion}

\subsection{Existing Conditions of Planning for Technical Competency Development at the Regional Secretariat of Purwakarta Regency}

The development of employee competence in Purwakarta Regency which has not been specifically regulated is about technical competence. The Regent's Regulation Number 104 of 2014 concerning Guidelines for Career Patterns for Civil Servants in the Purwakarta Regency Government explains more about the reasons for the need for employee career development. The policy states that for the smooth implementation of government duties in Purwakarta Regency, professional, creative, responsible and high-performance civil servants are needed, supported by competitive, selective and transparent career development.

The career pattern of civil servants in Purwakarta Regency is more illustrative of the career development path that has linkages and harmony between positions, ranks, education and training (training) positions, competencies, and the tenure of a civil servant from the first appointment in a certain position until retirement.

The pattern of developing the competence of civil servants carried out by the government of Purwakarta Regency in realizing professional apparatus resources basically follows the model that has been set in the policies of developing the competence of civil servants. The focus of civil servant competency development includes the development of technical, sociocultural, and managerial or leadership competencies through both classical and non-classical pathways. The development of the classical model of competence is through the implementation of education and training, both pre-service training and in-service training.

Existing conditions in the field indicate that the development of technical competence of employees, especially at the Regional Secretariat of the Purwakarta Regency Government has not been designed through a systematic, integrative, and synergistic planning model based on the needs of the organization, position, and individual employees themselves. The model for developing the competence of civil servants in Purwakarta Regency can be described at Diagram 2.

\subsection{Alternative Model of Planning for Technical Competency Development at the Regional Secretariat of Purwakarta Regency \\ The existing condition of the PNS competency development plan that has been implemented at the Purwakarta Regency Regional Secretariat shows that there are still various}


weaknesses. For this reason, this study will examine competency development planning using an alternative model formulated by Mukherjee (2011: 29).

As explained, this model includes seven stages, starting from organizational profiling, job profiling, identification of performance indicators, superior perspective of performance, compilation, defining competency, up to the finalization and validation stages.

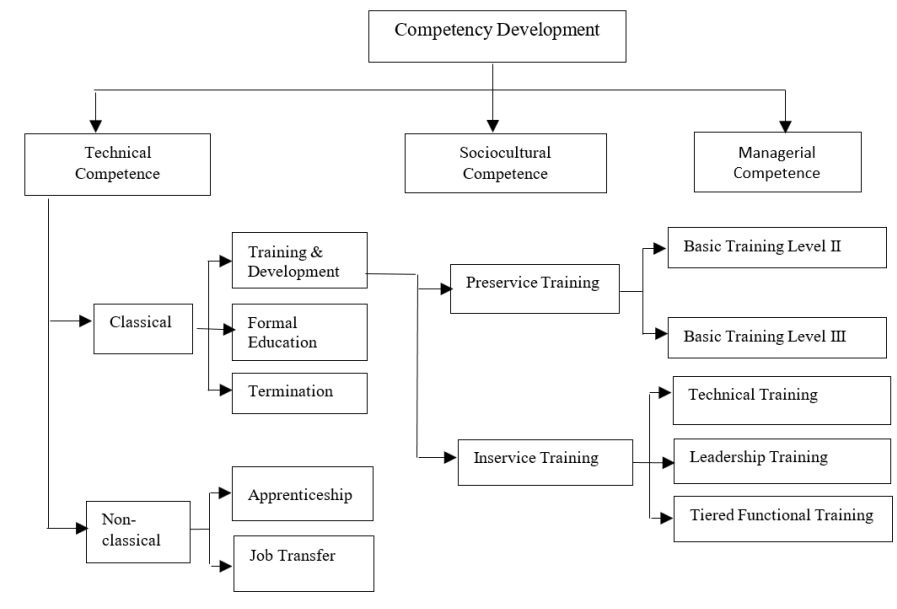

Fig 2. Forms of PNS Career Development in Purwakarta Regency

\subsection{Organization Profiling at the Regional Secretariat of Purwakarta Regency}

Competence development according to Mukherjee (2011:29) must be aligned with the organization's vision and mission as well as work plans as well as organizational tasks and functions. The vision of the Regional Secretariat of the Purwakarta Regency Government which is the reference for planning the development of civil servants' competencies is "The Realization of an Intelligent and Superior Regional Secretariat of the Purwakarta Regency Government Towards Character Purwakarta".

Based on this vision, civil servant competency development planning must be directed to the creation of intelligent, superior, and characterized civil servants. In accordance with its duties and functions, the Regional Secretariat as an institution that is able to work carefully, has a high work ethic, is responsive, disciplined and accountable, always tries to improve its capabilities and by utilizing the noble values of local cultural wisdom must answer every challenge it faces.

Planning for competency development must also be based on the mission of the Regional Secretariat of Purwakarta Regency as an elaboration of the vision that has been set. In this study, the missions that serve as guidelines for developing civil servants' competencies are: (1) Increasing the capacity of regional secretariats and other regional apparatus organizations dynamically and continuously; (2) Improving the performance of regional secretariats and other regional apparatus organizations for the realization of clean government and good governance; (3) Increasing the use of information and communication technology as well as cooperation with various parties in order to support efforts to improve the performance of all regional apparatus organizations and the realization of public information openness; (4) Strive to create synergy and continuity of programs and activities in all regional apparatus organizations; and (5) Develop a work culture that is always achievement-oriented and based on laws and regulations. 
The next organizational aspect that is considered in planning competency development is the work plan of the Regional Secretariat of Purwakarta Regency. The work plan is an elaboration of the regional development plan itself, in this case the Purwakarta Regency RPJMD is regulated by Purwakarta Regency Regulation Number 1 of 2019 concerning the Purwakarta Regency Medium-Term Development Plan (RPJMD) 2018-2023. The work plan of the Regional Secretariat of Purwakarta Regency contains a program that contains planned activities and follows the principle of aggregation or approach.

The program of activities related to the development of employee competencies within the Regional Secretariat of Purwakarta Regency is training and training activities for employees within the Purwakarta Regency Secretariat which details the activities of spending: courses, training, socialization, technical guidance, socialization, capacity building.

The achievement of the vision, mission and plans needs to be supported by competent employees. These three aspects of the organization will serve as a reference for the Regional Secretariat of Pusrwakarta Regency in drawing up plans for the development of its civil servants' technical competence.

\subsection{Job Profile (Job Profiling) Regional Secretariat of Purwakarta Regency}

The next step in planning competency development based on the Mukherjee (2011: 30) model is to develop a job profiling. According to him, this step involves understanding the organizational structure by reviewing detailed job descriptions for various level positions. The Regional Secretariat of Purwakarta Regency already has a position information document, which contains complete job requirements. However, the problem is that the job requirements in the document have not been used properly. For this reason, it is necessary to develop appropriate employee competencies in order to meet these prerequisite gaps. For this reason, the use of job information is an important part of planning employee competency development so that the Regional Secretariat of Purwakarta Regency is not wrong in determining what technical training is needed by employees.

Based on the job information document, it can be seen the profile of positions in the Purwakarta Regency Regional Secretariat which can be used as a reference for competency development planning. The positions in the Regional Secretariat along with their educational qualifications can be seen in the table 1 .

The position information document has clearly described the identity, description, and specifications of each position. Information about the description and specifications of each position can be used as the basis for determining employee competency development plans. From the results of job profiling in the Purwakarta Regency Regional Secretariat, it was found that the job requirements set out in the job information were not used as the basis for the placement or procurement of employees.

This can be seen from the discrepancy between the position criteria held by the employee with the provisions required in the position information document. For example, the educational qualification requirement for an analyst position is a bachelor's degree, but in fact employees with a Diploma Three education level are placed in that position. Another example, employees with a Bachelor of Social education background are placed in the finance work unit, whereas it is more appropriate to be placed in the work unit of the Social Welfare Division.

Based on the job profiling analysis, it can be concluded that there is a need for planning for the development of civil servants' competence at the Regional Secretariat of Purwakarta Regency to meet the discrepancy between the job requirements that have been set in the job information document with the criteria possessed by the civil servants themselves. 
Table 1. List of Positions at the Regional Secretariat of Purwakarta Regency

\begin{tabular}{cll}
\hline No & \multicolumn{1}{c}{ Job Position } & \multicolumn{1}{c}{ Education Background } \\
\hline 1. & Head of Governmental & $\begin{array}{l}\text { Bachelor of Islamic Religious } \\
\text { Education }\end{array}$ \\
\hline 2. & Head of Sub-Division of Social Welfare & Bachelor of Religion \\
\hline 3. & Head of Sub-Division of Natural Resources & Bachelor of Law \\
\hline 4. & Head of Economic Sub-section & Bachelor of Engineering \\
\hline 5. & Head of Organization & Bachelor of Economics \\
\hline 6. & Head of Institutional and Analysis Sub-Section & Bachelor of Law \\
\hline 7. & Head of Sub-Division of Public Service \& & Bachelor of Social \\
\hline 8. & Management & \\
\hline 9. & Head of Sub Division of Finance & Bachelor of Communication \\
\hline 10. & Head of Sub Division of Leadership & Bachelor of Social \\
\hline Communications & Cooperation Analyst & Bachelor of Economics \\
\hline 11. & Program and Activities Manager & Bachelor of Religion \\
\hline 13. & Facilities and Infrastructure Administration & Bachelor of Law \\
\hline 14. & Performance Analyst & Bachelor of Economics \\
\hline 15. & Salary Manager & Bachelor of Social \\
\hline 16. & Administrative Analyst & Bachelor of Economics \\
\hline 17. & Administrative Analyst & Bachelor of Islamic Religious \\
& & Education \\
\hline
\end{tabular}

(Source: Personnel Subdivision2019)

\subsection{Identification of Performance Indicators at the Regional Secretariat of Purwakarta Regency}

The next step in planning competency development in the Mukherjee model (2011:31) is to identify performance indicators. This is because competency development planning needs to be linked to efforts to improve the performance of the employees themselves. Therefore, it is necessary to determine in advance the performance indicators of each position in the organization. Moreover, the objectives of developing the competence of the employees of the Regional Secretariat of Purwakarta Regency are intended to: 1) utilize civil servants within the Purwakarta Regency Government to carry out their duties and responsibilities according to their level and competence; 2) develop abilities, skills and skills efficiently, effectively and rationally so that the talents, interests and motivations of employees can be channeled objectively; 3 ) harmonize the abilities, skills and skills of employees within the Purwakarta Regency Government according to the levels and assignments in available positions to produce optimal work performance; 4) create a conducive and transparent work climate so as to be able to provide work motivation and development of competence or self-potential for Civil Servants in the Purwakarta Regency Government as quality human resources.

In this study, the indicators used to predict employee performance are from the aspect of employee competence. The indicators used in this study include five characteristics developed by Spencer (1993) namely motives, traits, self-concepts, knowledge and skills. To identify the performance of the implementing staff at the Regional Secretariat of Purwakarta Regency, the researcher asked his immediate supervisor ( 9 Heads of Subdivisions) to assess the performance of the staff/implementers of 45 staff/executors consisting of managers, administrators and analysts, from the aspect of their work competence. 
The results of the assessment are as follows:

a. Most of the motive indicators are rated as Very Good and Good. This means that most of the staff / implementers already have a good work motive in carrying out their work.

b. Most of the trait indicators are rated Very Good and Good. This shows that most of the staff/implementers already have the good qualities needed in carrying out their duties.

c. Overall self-concept indicators have been rated Very Good and Good. This means that the staff at the Regional Secretariat of Purwakarta Regency already have a good self-concept, are able to manage themselves and place themselves as social beings. This good employee self-concept will create good social relationships and minimize conflict within the organization.

d. Indicators of working knowledge of employees at the staff/implementer level as a whole are still considered not good. This unfavorable assessment is especially for managers and administrators. This shows that the working knowledge of employees at the staff level still needs to be improved.

e. Indicators of employee work skills at the staff/implementer level as a whole are still considered poor. This means that employees still lack the work skills required by the field of work or organization.

The results of the assessment can clearly be seen in the table 2 .

Based on the identification of these performance indicators, it can be concluded that there is a competency development plan for staff level employees in managerial, administrative, and analyst positions, especially on indicators of knowledge and work skills. The development of employee competencies that need to be planned is of course related to the technical knowledge and skills required by each of these positions.

\subsection{Superior Perspective of Performance at the Regional Secretariat of Purwakarta Regency}

The next stage in planning competency development in the model according to Mukherjee (2011: 31) is determining the performance excellence achieved by employees. Superior perspective of performance can be interpreted as superior performance perspective. Superior means superior, very high quality, and great. And when combined with superior performance, it means doing the best work and based on joy so as to produce truly superior work. Based on the previous meaning, it appears that superior performance becomes an integral part of an organizational process.

Table 2. Employee Motives at the Regional Secretariat of Purwakarta Regency

\begin{tabular}{|l|c|c|c|c|}
\hline \multirow{2}{*}{\multicolumn{1}{|c|}{ Indicators }} & \multicolumn{3}{|c|}{ Job Position } & \multirow{2}{*}{ Total } \\
\cline { 2 - 4 } & Administrator & Clerk & Analist & \\
\hline 1. Motive & & & & \\
\hline Very Not Good & 0 & 0 & 2 & 2 \\
\hline Not good & 2 & 0 & 0 & 2 \\
\hline Good & 16 & 1 & 8 & 25 \\
\hline Very good & 10 & 2 & 4 & 16 \\
\hline 2. Trait & & & & \\
\hline Very Not Good & 0 & 0 & 2 & 2 \\
\hline Not good & 1 & 0 & 0 & 1 \\
\hline Good & 15 & 2 & 10 & 27 \\
\hline
\end{tabular}




\begin{tabular}{|l|c|c|c|c|}
\hline \multirow{2}{*}{ Indicators } & \multicolumn{3}{|c|}{ Job Position } & \multirow{2}{*}{ Total } \\
\cline { 2 - 4 } & Administrator & Clerk & Analist & 15 \\
\hline Very good & 12 & 1 & 2 & \\
\hline 3. Self Concept & & & 1 & 2 \\
\hline Very Not Good & 1 & 1 & 2 & 13 \\
\hline Not good & 10 & 1 & 7 & 21 \\
\hline Good & 13 & 1 & 4 & 9 \\
\hline Very good & 12 & & & \\
\hline 4. Work & & 1 & 0 & 12 \\
\hline Knowledge & 10 & 2 & 8 & 25 \\
\hline Very Not Good & 15 & 0 & 4 & 7 \\
\hline Not good & 3 & 0 & 2 & 2 \\
\hline Very good & 0 & & & \\
\hline 5. Skill & & 2 & 0 & 8 \\
\hline Very Not Good & 6 & 1 & 6 & 24 \\
\hline Not good & 17 & 0 & 6 & 11 \\
\hline Good & 5 & 0 & 2 & 2 \\
\hline Very good & 0 & & & \\
\hline Source: Wildan & & & & \\
\hline
\end{tabular}

(Source: Wildan, 2020)

Performance is an achievement that results from a process or way of acting in a task. Performance is related to employee activities in carrying out work assigned to produce goods or services based on the standards used by the organization in achieving its goals. Therefore, the indicators used in conducting performance appraisals must meet the requirements in order to obtain accurate information about the work and the implementation of the work as its main task. There are five requirements that must be met in conducting a performance appraisal in order to obtain effective results according to Cascio and Award as quoted by Soeprihanto (2001:9), namely: (1) Reliability, (2) Relevance, (3) Sensitivity, (4) Practicality, and (5) Acceptability.

These five criteria are used by researchers to assess how superior the performance of employees at the Regional Secretariat of Purwakarta Regency is. The assessment was carried out by 45 employees on the suitability of the employee's work targets (KPI) in meeting the five criteria for superior performance appraisal. The results of the employee assessment are as follows:

Table 3. Employee Assessment of KPI in the Perspective of Superior Performance

\begin{tabular}{|c|c|c|c|c|}
\hline \multirow{2}{*}{ Aspect } & \multirow{2}{*}{$\begin{array}{c}\text { Criteria } \\
\text { Evaluation }\end{array}$} & \multicolumn{3}{|c|}{ Job Position } \\
\cline { 3 - 5 } & & Adminitrator & Clerk & Analist \\
\hline \multirow{3}{*}{ Relevance } & Yes & 19 & 0 & 9 \\
\cline { 2 - 5 } & Not & 9 & 3 & 5 \\
\hline \multirow{2}{*}{ Acceptability } & Yes & 11 & 1 & 7 \\
\cline { 2 - 5 } & Not & 17 & 2 & 7 \\
\hline \multirow{2}{*}{ Reliability } & Yes & 11 & 0 & 3 \\
\cline { 2 - 5 } & Not & 17 & 3 & 11 \\
\hline
\end{tabular}




\begin{tabular}{|c|c|c|c|c|}
\multirow{3}{*}{ Sensitivity } & Yes & 12 & 0 & 4 \\
\cline { 2 - 5 } & Not & 16 & 3 & 10 \\
\hline \multirow{2}{*}{$\begin{array}{c}\text { Kepraktisan } \\
\text { (Practically) }\end{array}$} & Yes & 19 & 3 & 11 \\
\cline { 2 - 5 } & Not & 9 & 3 & 3 \\
\hline
\end{tabular}

(Source: Wildan, 2020)

Based on the data in the table can be analyzed as follows:

a. Relevance implies that there must be a clear link between the performance standards of a job and the goals of the organization. In addition, there is a clear relationship between the elements in the work and the dimensions assessed in the assessment sheet. The results of the study indicate that the overall performance assessment with KPI at the Regional Secretariat of Purwakarta Regency can be said to be 'relevant'. This means that the employees of the Purwakarta Regency Regional Secretariat feel that the employee performance appraisal through the KPI instrument has described the main duties and functions of the employee.

b. Acceptability or acceptability is the most important requirement among other performance appraisal systems, because human resource development programs must have the support of the people who will implement them. The results of the study indicate that the overall performance assessment with KPI at the Regional Secretariat of Purwakarta Regency can be said to be 'not Acceptability'. This means that the employees of the Regional Secretariat of Purwakarta Regency dominantly feel that employee performance appraisals are carried out through the KPI instrument, the appraisal process is more confidential and the results of the assessment are not communicated openly by their direct superiors or there is no follow-up on the assessment of the shortcomings or weaknesses of employee performance that must be improved, so that the appraisal process tend to be biased and more subjective.

c. Reliability means that the results of an assessment system must be reliable and consistent. A performance appraisal system is said to have a high element of reliability if two or more appraisers give mutually appropriate ratings, but assessing from different perspectives (e.g., superiors, co-workers, subordinates) can see the performance of the same individual very differently. The results of the study show that the overall performance assessment with KPI at the Regional Secretariat of Purwakarta Regency can be said to be 'not reliable'. This means that the employees of the Regional Secretariat of Purwakarta Regency dominantly feel that employee performance appraisals through the KPI instrument, only assess based on the results of observations/performance appraisals at the last time approaching the time of the assessment period, inconsistent and without paying attention to past performance achievements.

d. Sensitivity implies that the performance appraisal system must be able to distinguish employees who work productively with employees who work less productively. The assessment system used can distinguish between effective employees and ineffective employees. The results of the study show that the overall performance assessment with KPI at the Regional Secretariat of Purwakarta Regency can be said to be 'not sensitive'. This means that the employees of the Regional Secretariat of Purwakarta Regency dominantly feel that employee performance appraisals through the KPI instrument are unable to reflect the differences between productive and unproductive employees, cannot be used as an assessment and measurement of how much productivity or a person's ability to complete work and employee contributions to the organization have not been. able to provide a comprehensive assessment. 
e. Practicality implies that the performance appraisal instrument is easy to understand by the appraiser and the appraiser. From this perspective, relevance, sensitivity, and reliability are actually technical components of a performance appraisal system designed to make decisions regarding employee performance. Easy to understand and use by managers and employees, uncomplicated and uncomplicated. The results showed that the performance assessment with KPI at the Regional Secretariat of Purwakarta Regency could be said to be "Practical". This means that Purwakarta Regency Regional Secretariat employees dominantly feel employee performance appraisals through the KPI instrument, this KPI assessment is easy to understand and can be applied practically and data deficiencies or errors are not too disturbing, the results of the assessment calculations are only limited to ratings and do not go through the process of taking values deeply by direct supervisor.

From these results, it can be said that in planning the development of employee competencies at the Regional Secretariat of Purwakarta Regency, the perspective of superior performance in SKP assessment aspects that need attention are acceptance, reliability, and sensitivity in identifying superior performances that can distinguish performance achievement between one another. employee with other employees.

\subsection{Employee Competency Gap Compilation at the Regional Secretariat of Purwakarta Regency}

The compilation stage means to collect the results of the comparison of the competency profile of civil servants with the competency standards of the position occupied and/or to be occupied. The results of this competency gap can be obtained through competency tests conducted by internal government assessors or in collaboration with independent assessors or can use the competency assessment method in the form of a superior-subordinate dialogue.

Good planning is preceded by identification of needs. Education and training needs can be seen by comparing the expected level of knowledge and abilities (as seen in the mission, functions and duties) with the knowledge and abilities that are actually owned by employees. Education and training are considered as important factors in improving the performance of employees, processes and organizations, it is widely recognized. But the problem is that much of the education and training provided by an organization does not or does not meet the real needs. For example, what is really needed is training B but what A does, as a result the investment invested through education and training is less visible.

From the results of the study, it can be said that the Regional Secretariat of Purwakarta Regency actually has the prerequisites for educational positions and technical competencies that are in accordance with their field of work. However, in reality, the prerequisite for technical competence is not a pre-position requirement, but can be fulfilled after occupying the position. This technical competency gap almost occurs in all implementing positions at the Regional Secretariat of Purwakarta Regency, so it is necessary to inventory technical training needs according to their field of work for planning the development of technical competencies that will be proposed in the next fiscal year.

\subsection{Defining Technical Competency at the Regional Secretariat of Purwakarta Regency}

The next stage is defining competency, which means determining technical competencies that are in accordance with organizational competency needs. In determining the development of technical competence will be more optimal if it is based on the interests of employees, so it is necessary to find the direction, interests and talents of employees. Currently the Regional Secretariat of Purwakarta Regency has not maximized the employee competency development program. Programs and activities related to competency development, namely increasing the 
capacity of apparatus resources are often not realized, this is more constrained by the element of permission from the direct superior.

Employees at the Regional Secretariat of Purwakarta Regency prefer to complete a series of work assignments as a priority. The direct supervisor's assessment does not include its employees in training in the context of developing their competence, mostly because after completing the training, the employee is unable to transfer the knowledge he has gained to his co-workers and some even switch tasks so that the post-training knowledge is implemented in the world of work.

Based on the results of research conducted at the Regional Secretariat of Purwakarta Regency, in general, the quality of employees, especially at the staff/implementer level, with a sample of 28 managers, 3 administrators and 14 analysts, turns out that competence in terms of knowledge and skills is still relatively low. This can be seen from the lack of understanding of the organization's goals/objectives, the difficulty of understanding the information conveyed by the organization such as understanding the applicable policies or regulations, systems and procedures that apply as the basis for carrying out work. The level of knowledge and skills that are in accordance with the needs or in accordance with the work to be completed, then the achievement of performance as expected will be realized.

Human resource development can be through training and development programs. Training programs seek to maintain and improve ongoing job performance while development programs are designed to instill skills in the future. Training needs can be determined through performance appraisals, job requirements, organizational analysis and human resource surveys. This training need must be adjusted to the direction, interests and talents of employees who have been neglected by the organization. There are 6 (six) types of employees' interests and directions according to Holland's theory, namely realistic, enterprising, conventional, social, artistic, investigative. The results of the study obtained the following data:

Table 4. Identification of Employee Interest in the Regional Secretariat

\begin{tabular}{|l|c|c|c|c|}
\hline \multirow{2}{*}{ Interest } & \multicolumn{3}{|c|}{ Job Position } & Total \\
\cline { 2 - 5 } & Adminitrator & Clerk & Analist & \\
\hline Realistis & 1 & 1 & 5 & 7 \\
\hline Enterprising & 0 & 0 & 4 & 4 \\
\hline Conventional & 17 & 2 & 0 & 19 \\
\hline Social & 4 & 0 & 0 & 4 \\
\hline Artistik & 5 & 0 & 2 & 7 \\
\hline Investigative & 1 & 0 & 3 & 4 \\
\hline
\end{tabular}

(Source: Wildan, 2020)

From the results of this study, it can be seen that at the Regional Secretariat of Purwakarta Regency of 45 (forty five) people consisting of 28 managers, 3 administrators and 14 analysts, it means that employees at the staff/executive level with the position of manager and administrator domination conventional means likes work that deals with files and numbers that are orderly and quickly bored to do explanations on an ongoing basis. Meanwhile, the staff/executive with the position of analyst with realistic dominance means that they like the type of work that involves a lot of physical activity that requires expertise, strength, and coordination, not so much concerned with theory, the important thing is that they do it according to practice.

Thus, it can be said that the placement of existing analyst employees is in accordance with their direction and interests. However, managers and administrators must be given training in the context of developing their competencies so that the knowledge they gain is growing. 


\subsection{Finalization and Validation of the Planning Model for Technical Competency Development at the Regional Secretariat of Purwakarta Regency}

The last stage is finalization and validation. Finalize the model by making adjustments or improvements, whether it is reduction or addition. The alternative model of planning for the development of technical competence of employees developed by researchers more elaborates on every aspect in its stages so that it is felt to be more complicated and time consuming. So there needs to be simplification in understanding every aspect of the stages. However, in essence, the aspect stages are generally the same as the concept developed by LAN in accordance with rule from LAN Number 10/2018.

The Civil Service Subdivision of the General Section of the Regional Secretariat of Purwakarta Regency as a subsection of the regional apparatus organizational unit submits a proposal for technical training needs for the next fiscal year through the Development section of the Purwakarta Regency Regional Secretariat. These proposals were summarized in the planning of the Regional Secretariat of Purwakarta Regency and thoroughly discussed by the Regional Development Planning, Research and Development Agency at the Regency community planning forum.

The urgency of the recapitulation of the proposal was seen by the authorized official, in this case the Regent of Purwakarta at the meeting to discuss the proposed policy ceiling for General Budget - Temporary Budget Ceiling Priority. If corrected, the proposal needs to be readjusted according to the direction of the competent authority, both from the quantity of the type of training and from the budget ceiling. However, if approved, the proposed training will be included in the list of activities for the next fiscal year which is ratified by the Purwakarta Regency Regional Regulation.

The validation of the alternative model for planning the development of technical competence at the Regional Secretariat of Purwakarta Regency was carried out by expert judgment, meaning asking for views from several people who are experts or competent in their fields. The model developed by this researcher has been in consultation with several stakeholders such as the Head of the Education and Training Subdivision of the Personnel and

Human Resources Development Agency and the Personnel and Administration Subdivision of Leaders so that this model is not only completed in theoretical studies but can also be applied. The proposed technical training is planned to be assisted or re-examined by the Regional Finance and Assets Agency, the Development Section of the Purwakarta Regency Regional Secretariat and the Research and Development Planning Agency.

The Regional Finance and Assets Agency conducts an examination of the conformity of the entry of the ceiling amount with the approved ceiling provisions, the suitability of the proposed price to be in accordance with the technical guidelines for the current budget year and the standard unit price that has been set with effective and efficient principles. The Development Section of the Regional Secretariat of Purwakarta Regency conducted an examination of activity indicators, activity rationale, and activity benchmarks from proposed technical training activities.

Bappedalitbangda checks the suitability of the activity nomenclature account code with the required proposals as well as the output of activity achievements. If the Regional Finance and Assets Agency, the Regional Secretariat of Purwakarta Regency and Bappedalitbangda have accepted it, it can be said that the proposed technical training proposal is valid and can be implemented in the current budget year. 


\section{Conclusion and Recommendation}

The conceptual model of employee competency development planning can be applied at the Regional Secretariat of Purwakarta Regency to increase the effectiveness of competency development itself. The planning model that needs to be developed starts from the identification and analysis stage of the organization concerning the vision, mission, organizational strategy, and goals to be achieved by the organization. This competency development plan is expected to be able to increase the capacity and ability of employees to work carefully, have a high work ethic, be responsive, disciplined and accountable.

Planning for competency development at the Regional Secretariat of Purwakarta Regency is supported by the availability of complete job information, as well as a job analysis team and an institutional evaluation team and preparation of job duties details. Although the competence of employees in terms of knowledge and skills which are still lacking plus performance appraisal using the SKP method/format (employee performance targets) does not reflect the real performance of employees in the field.

From the results of the research, the Regional Secretariat of Purwakarta Regency feels the need for planning for the development of technical competence of employees in accordance with the direction of the interests and talents of the employees. Training and development in accordance with the field of work required by the organization will help improve employee competencies and overcome competency gaps that occur within the organization. Training that is prepared in a planned and programmed manner which is then realized with full consistency will create a conducive organizational situation.

\section{References}

[1] Fathurrochman, Irwan. 2017. Competence Development of State Civil Apparatus Employees (ASN) Curup Islamic High School (STAIN) Through Education and Training Methods. Journal of Education Management, Vol 11, No 2. (accessed February 6, 2020).

[2] Gouzali, Saydam. 2005. Human Resource Management: A Micro Approach. Jakarta: Djambaran.

[3] Gunawan, Imam. 2015. Qualitative Research Methods. Jakarta: Character.

[4] Gutteridge, Thomas G. 1976. Commentary: A comparison of Perspective, Career in Organizational. In L. Dyer (Ed.), Careers in organizations: Individual planning and organizational development. Ithaca N.Y: Cornell University

[5] Hasibuan, Malay S.P. 2008. Human Resource Management. Jakarta: Earth Literacy.

[6] Juhaeni, Yuyu Siti. 2019. Guidelines for Planning for Employee Competency Development within the Ministry of Trade" Ministry of Trade. STIA LAN Jakarta Vol 3, No 1 https://http://180.250.247.102/conference/index.php/knia/article/view/56/pdf (accessed August 6, 2020).

[7] Kadarisman, M. 2013. Human Resource Development Management. Depok: King of Grafindo

[8] Mukherjee, Sraban Dr. 2011. Competency Mapping For Superior Results. New Delhi: McGraw-Hill Office

[9] Ngindana, Rispa, Dan Hermawan, Romy. 2019. Analysis of Civil Servant Training Needs Based on Work Unit Gaps in the Mojokerto City Government, Journal of Social and Political Science Innovation, Vol. 1, No. April 1, 2019 Pages: $1-11$.

[10] Palaniappan, R. 2003. Competency Management-A Practitioner's Guide. Kuala Lumpur: Suma Printing.

[11] Regulation of the Head of the State Civil Service Agency Number 22 Year 2013 concerning Guidelines for the Preparation of Civil Servant Development Planning.

[12] Regulation of the Head of the State Civil Service Agency Number 3 Year 2013 concerning Guidelines for the Implementation of Technical Education and Training for Education and Training Needs Analysis. 
[13] Regulation of the State Administration of the Republic of Indonesia Number 10 Year 2018 concerning the Competence Development of Civil Servants.

[14] Regulation of the Minister for Empowerment of State Apparatus and Bureaucratic Reform of the Republic of Indonesia No. 38 Year 2017 concerning Competency Standards for State Civil Apparatus Positions.

[15] Government Regulation 101Year 2000 concerning Education and Training for Civil Servants.

[16] Government Regulation No. 17 Year 2020 concerning Civil Servant Management. Amendment to Indonesian Government Regulation No. 11 of 2017 concerning the Management of Civil Servants.

[17] Government Regulation Number 30 Year 2019 concerning Performance Assessment of Civil Servants.

[18] Sartika, D. \& Kusumaningrum, M. 2017. Competence Development of State Civil Apparatus in the Government of East Kalimantan Province. Journal of Borneo Administrator, 13(2), 131-150.

[19] Satari, Armeini Uha. 2006. Social Organization and Leadership. In: Definition and Objectives and Types and Structure of Social Organizations. Open University, Jakarta, pp. 1-28. ISBN 9796897180 http://repository.ut.ac.id/4454/1/LUHT4327-M1.pdf (accessed June 6, 2020)

[20] Sedarmayanti. 2017. Human Resource Planning and Development to Improve Competence, Performance and Work Productivity. Bandung: Refika Aditama

[21] Spencer, L. M., \& Spencer, P. S. M. 1993. Competence At Work Models for Superior Performance. John Wiley \& Sons.

[22] Terry, George R. 2005. Principles of Management. New York: Alexander Hamilton Institute

[23] Titus Sano, Joyce J Rares and Martha Ogotan. 2018. Development of State Civil Apparatus Competence at the Education Office of Intan Regency

[24] Jaya, Papua Province. Sam Ratulangi University E-Journal: 18451. https://ejournal.unsrat.ac.id/index.php/JAP/article/viewFile/18451/17979 (accessed February 3, 2020)

[25] Ulrich, Dave. 1998. Intellectual Capital = Competence $\mathrm{x}$ Commitment. Sloan Management Review.

[26] Republic of Indonesia Law Number 5 Year 2014 concerning State Civil Apparatus.

[27] Usmara. 2002. New Paradigm of Human Resource Management. Yogyakarta: CV Asmara Books.

[28] Werner, Jon M \& Randy L. Desimone. 2012. Human Resource Development. Canada: Ennge Learning.

[29] Winkel, W.s \& Sri Hastuti. 2006. Guidance and Counseling at the Institute of Education. Jakarta: PT. Grasindo. 